
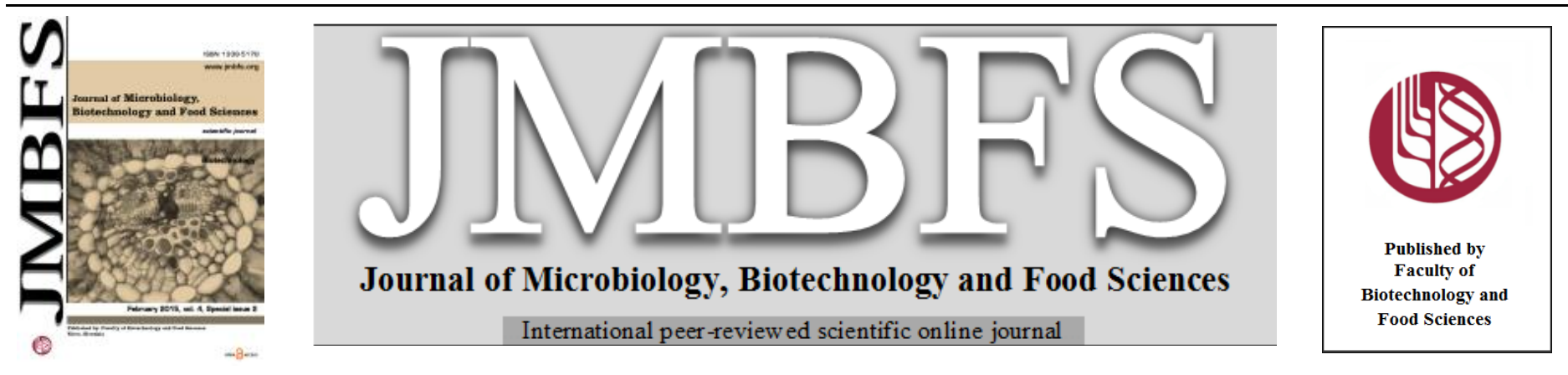

\title{
DYNAMIC OF CHANGES OF BLOOD PLASMA ENERGY METABOLISM PARAMETERS IN SUCKLING COWS DURING CALVING INTERVAL
}

\section{Ales Pavlik*}

Address(es):

Mendel University in Brno, Department of Morfology, Physiology and Animal Genetics, Zemedelska 1,613 00 Brno, Czech republic.

*Corresponding author: pavlik@ mendelu.cz

doi: 10.15414/jmbfs.2015.4.special2.92-93

\section{ARTICLE INFO}

Received 5. 11. 2014

Revised 10. 12. 2014

Accepted 2. 1. 2015

Published 2. 2. 2015

Regular article OPEN $\partial_{\text {ACCESS }}$

\begin{abstract}
In this study, effect of environmental condition changes during gazing period on energy metabolism parameters was investigated. Totally 40 Aberdeen Angus cows were selected for observation. Calving all of cows was situated into March. The feeding ration for the animals was comprised by pasture during the grazing period and corn silage, hay and granulated distiller's grains during the winter period. At average age 9 days before calving, and subsequently 10, 81, 151, 189 and 273 days after calving, blood was sampled and analysed for glucose and NEFA (non-esterified fatty acid) concentrations on KONELAB T20xt automatic analyser (Thermo Fisher Scientific, Finland) and currently available commercial kits (Biovendor-Laboratorni medicina, Czech Republic). A rapid increase ( $p<$ 0.05 ) of glucose concentration was detected in blood plasma of cows in period before calving to 81 days post partum. Average value of glucose concentration at 273 days postpartum was significant $(p<0.05)$ lower comparing to day 189. The highest concentrations of NEFA in blood plasma of cows were found at 10 day postpartum. After that, during the persisted higher temperature period the NEFA concentration decreased significantly $(p<0.01)$ till 189 days postpartum. At the end of monitored period concentration of NEFA in blood plasma significantly decreased $(p<0.05$ ). Changes of hot and cold season during the grazing period probably according to forage quality and had significant effects on blood plasma NEFA and glucose concentrations.
\end{abstract}

Keywords: Beef cows, non-esterified fatty acid, glucose, blood plasma

\section{INTRODUCTION}

In beef cattle during the grazing, the nutrition is influenced by seasonal fluctuations in the nutritive quality of rangelands, which subsequently affects diet composition and selectivity of grazing cattle (Obeidat $\boldsymbol{e t}$ al., 2002). Poppi and McLennan (1995) and Devendra and Sevilla (2002) reported that during the early to mid hot-wet season, rangelands are not an adequate source of energy. These changes are accompanied by decreased in degradation and fermentation ruminal and therefore affected nutritional state of grazing cattle. It is well recognized that nutritional state of the grazing cattle is related with blood glucose and non-esterified fatty acids as well as another metabolic parameters (Agenas $\boldsymbol{e t}$ al., 2006; Yokus and Cakir, 2006; González-Garcia et al., 2011). Owens et al. (1991) suggested that evaluation of metabolite and hormone profiles is paramount to our understanding of biochemical mechanisms at work in the grazing animal. Nevertheless, the information concerning the relationship between diet quality, ruminal environment and nutrient utilization in grazing cattle is quite limited. This study supposes that blood concentrations of glucose and non-esterified fatty acids are sensitive to seasonal changes in the nutritive quality and ruminal fermentation of diet consumed by grazing beef cattle.

\section{MATERIALS AND METHODS}

The experiment was conducted on a farm in the foothills of the Orlicke Mountains. The elevation in this area is around $500 \mathrm{~m}$ a.s.l., and the total annual precipitation is an average $728 \mathrm{~mm}$ per year. The average monthly air temperatures and relative air humidity are indicated in figure 1 . Totally 40 Aberdeen Angus cows were selected for observation. Calving all of cows was situated into March. The feeding ration for the animals was comprised by pasture during the grazing period and corn silage, hay and granulated distiller's grains during the winter period. At average age 9 days before calving, and subsequently $10,81,151,189$ and 273 days after calving, blood was sampled from the vena caudalis mediana using the HEMOS sampling system. These blood samples were stabilised with heparin. The blood was centrifuged at $2000 \mathrm{~g}$ for 15 minutes. The blood plasma was stored at a temperature of $-20^{\circ} \mathrm{C}$ until analysed. From the blood plasma, the concentration of glucose and NEFA were measured. Biochemical indicators were analysed on KONELAB T20xt automatic analyser
(Thermo Fisher Scientific, Finland) and currently available commercial kits (Biovendor-Laboratorni medicina, Czech Republic). Statistical analysis of the obtained data was performed using the STATISTICA 8.0 programme by singlefactor analysis of variance for factor animal age. ANOVA was followed by posthoc Fisher's LSD test for pair-wise comparisons, when appropriate. The overall levels of statistical significance were defined as $p<0.05$ and $p<0.01$.

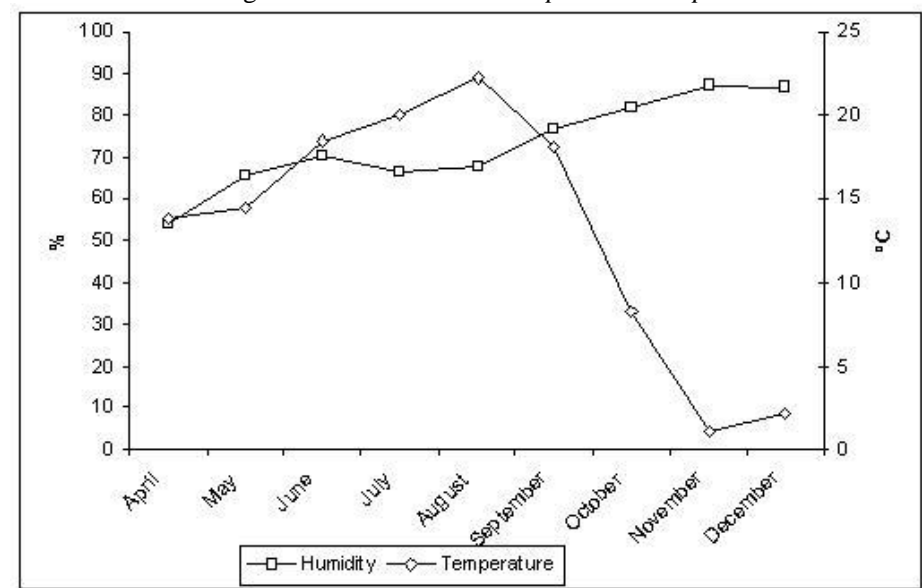

Figure 1 Average air temperatures and relative air humidity during the examined period

\section{RESULTS AND DISCUSION}

Average values of the concentrations of glucose and NEFA are given in figures 2 and 3. Changes in concentration of plasma glucose were recorded during the experiment. A rapid increase $(p<0.05)$ of glucose concentration was detected in blood plasma of cows in period before calving to 81 days post partum. Consequently we found slight non significant changes until 189 days post partum. Average value of glucose concentration at 273 days postpartum was significant $(p<0.05)$ lower comparing to day 189. The highest concentrations of 
NEFA in blood plasma of cows were found at 10 day postpartum. After that, during the persisted higher temperature period the NEFA concentration decreased significantly $(p<0.01)$ till 189 days postpartum. At the end of monitored period concentration of NEFA in blood plasma significantly decreased $(p<0.05)$. The mean values of glucose and NEFA in cows were within the normal physiologica range for cattle (Otto et al., 2000; Ndlovu et al., 2009). The plasma glucose concentrations found in the present study are also according with concentrations reported by Hersom et al. (2004) in grazing cattle. Plasma glucose concentrations were highest in summer that is the season when cattle selected a diet with higher content of soluble carbohydrates, which is consistent with the fact that glucose is closely related with changes seasonal in forage quality (Waterman et al., 2007). The concentration of NEFA was significantly greater in animals grazing in spring than in summer according to findings of Mapieye $\boldsymbol{e}$ al. (2010). However Abeni et al. (2004) mentioned that in grazing cattle, blood NEFA concentrations should increase with maturity forage, which could indicate a negative energetic balance. They suppose that during the dry period the lipolytic pathways increased in activity in order to generate energy from body energy reserves, which let to increase NEFA during the period of greater scarcity of forage. This tendency we do not found in this study.

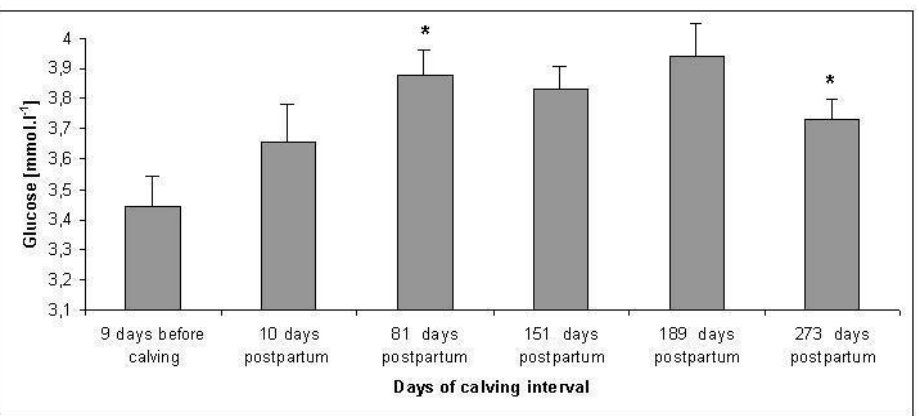

Figure 2 Concentrations of glucose in the blood plasma of Aberdeen Angus cows during the calving interval. Data in the columns present mean and confidence interval. *.... $(p<0.05)$.

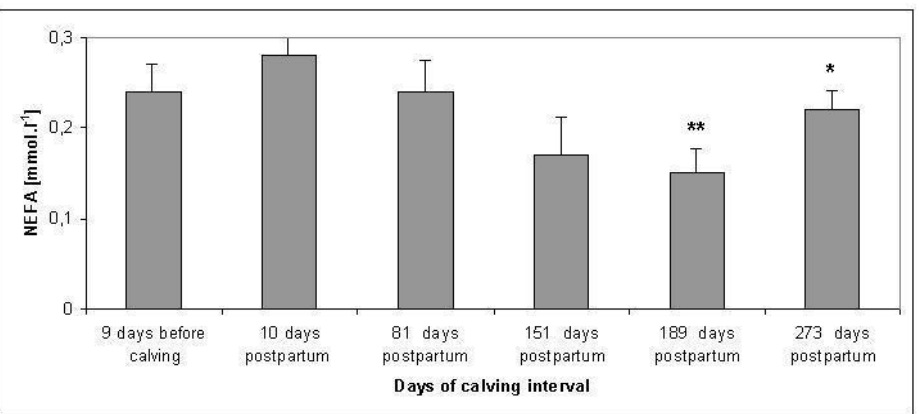

Figure 3 Concentrations of glucose in the blood plasma of Aberdeen Angus cows during the calving interval. Data in the columns present mean and confidence interval. *.... $(p<0.05),{ }^{*} * \ldots . .(p<0.01)$

\section{CONCLUSION}

Based on our results in this study, we could conclude that changes of hot and cold season during the grazing period probably according to forage quality had significant effects on blood plasma concentrations of glucose and NEFA in blood plasma of Aberdeen Angus cows.

Acknowledgments: The present study was supported by the project of National Agency for Agricultural Research no. QH 71156.

\section{REFERENCE}

ABENI, F., BERGOGLIO, G., MASOERO, G., TERZANO, G.M. ALLEGRINI, S. 2004. Plasma hormones and metabolites in Piedmontese cows dutiny late pregnancy: relationships with calf birthweight. Journal of Animal Science. 82, 438-444.

AGENAS, S., HEATH, M.F., NIXON, R.M., WILKINSON J.M., PHILLIPS, C.J.C. 2006. Indicators of undernutrition in cattle. Animal Welfare. 15(2), 149160.

DEVENDRA, C., SEVILLA, C.C. 2002. Availability and use of feed resources in crop-animal systems in Asia. Agricultural Systems. 71(1-2), 59-73. http://dx.doi.org/10.1016/S0308-521X(01)00036-1

GONZÁLEZ-GARCIA， E., DEBUS, N., HASSOUN, P., CAMOUS, S AUREL, M.R., BOCQUIE, F., BARILLET, F. 2011. Blood metabolites and hormones as potential markers of body reserves dynamic balance in ruminants (abstract). Journal of Animal Science. 89, (Suppl. 1), 443.
HERSOM, M.J., WETTEMANN, R.C., KREHBIEL, C.R., HORN, G.W., KESILER, D.H. 2004. Effect of live weight gain of steers dutiny wintergrazing. III. Blood metabolites and hormones dutiny feedlot finishing. Journal of Animal Science. 82, 2059-2068.

MAPIYE, C., CHIMONYO, M., DZAMA1, K., MARUFU, M.C. 2010. Seasonal Changes in Energy-related Blood Metabolites and Mineral Profiles of Nguni and Crossbred Cattle on Communal Rangelands in the Eastern Cape, South Africa. Asian-Australian Journal of Animal Science. 23(6): $708-718$ http://dx.doi.org/10.5713/ajas.2010.90419

NDLOVU, T., CHIMONYO, M., MUCHENJE, V. 2009. Monthly changes in body condition scores and internal parasite prevalence in Nguni, Bonsmara and Angus steers raised on sweetveld. Tropical Animal Health and Production. 41(7), 1169-1177. http://dx.doi.org/10.1007/s11250-008-9297-0

OBEIDAT, B.S., THOMAS, M.G., HALLFORD, D.M., KEISLER, D.H., PETERSEN, M.K., BRYANT,W.D., GARCIA, M.D., NARRO, L., LOPEZ, R. 2002. Metabolic characteristics of multiparous Angus and Brahman cow grazing in the Chihuahua desert. Journal of Animal Science. 80, 2223-2233.

OTTO, F., BAGGASSE, P., BOGIN, E., HARUN, M., VILELA, F. 2000 Biochemical blood profile of Angoni cattle in Mozambique. Israel Veterinary Medical Association. 55(3), 1-9.

OWENS, F.N., GARZA, J., DUBESKI, P. 1991. Advances in amino acid and N nutrition in grazing ruminants. Proccedings of 2 nd Grazing Livestock Nutritional Conference. Oklahoma Agricultural Experiment Station MP.-133, Stillwater, Oklahoma: 109-129.

POPPI, D.P., MCLENNAN, S.R. 1995. Protein and energy utilisation by ruminants at pasture. Journal of Animal Science. 73, 278-290.

WATERMAN, R.C., GRINGS, E.E., GEARY, T.W., ROBERTS, A.J., ALEXANDER, L.J., MACNEIL, M.D. 2007.Influence of seasonal forage quality on glucose kinetics of young beef cows. Journal of Animal Science. 85, 25822595. http://dx.doi.org/ 10.2527/jas.2007-0023

YOKUS, B., CAKIR, U.D. 2006. Seasonal and physiological variations in serum chemistry and mineral concentrations in cattle. Biological Trace Element Research. 109, 255-266. http://dx.doi.org/ 10.1385/BTER:109:3:255 